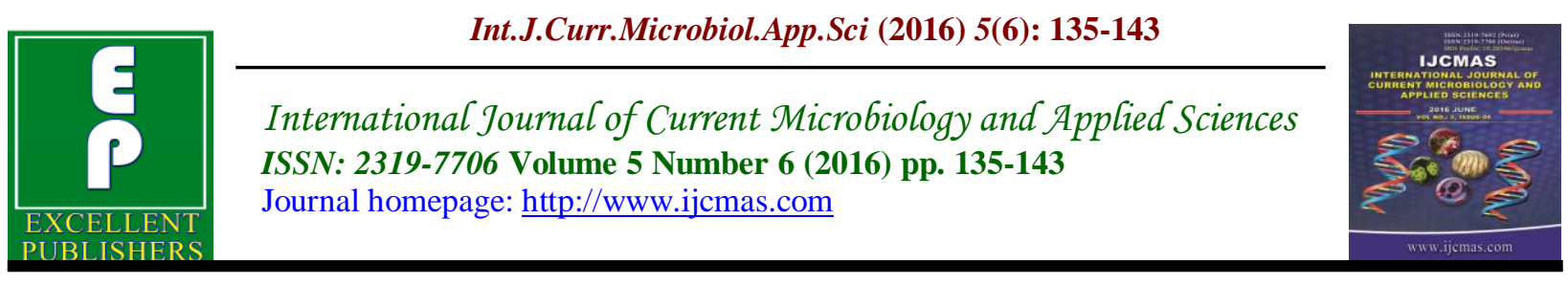

Original Research Article

http://dx.doi.org/10.20546/ijcmas.2016.506.017

\title{
Morphological and Molecular Diversity of Cordia dichotoma Frost F. Populations from Nanded District in Maharashtra, India
}

\author{
Pushpa H. Nandedkar* and Ramjan M. Mulani \\ DST-FIST Sponsored, School of Life Sciences, Swami Ramanand, Teerth, Marathwada, \\ University, Nanded, India \\ *Corresponding author
}

\begin{abstract}
A B S T R A C T
Keywords

Cordia dichotoma, Evolution, Genetic diversity, Morphology, RAPD.

\section{Article Info}

Accepted:

11 May 2016 Available Online:

10 June 2016

The Present study reveals the morphological and molecular variations in different accessions of Cordia dichotoma Frost F. a medicinally important plant collected from different locations of the Nanded district in Maharashtra, India. Morphological characterization of 10 year-old trees for 10 traits indicated wide variations among the accessions tested. Higher number of fruits per cyme and higher pulp: stone ratio was found in accession NCd7 colleted from Pawdewadi. Overall, NCd7 was found to be a superior germplasm line for most of the horticulturally useful traits among the accessions tested as it had higher percent of fruit set, pulp:stone ratio and fruit weight. High significant positive correlation was obtained between leaf, fruit characters and pulp:stone ratio. Moleuclar analysis was carried out using RAPD markers. Out of the five primers screened, a total of 45 scorable polymorphic markers were generated. Average polymorphism resolved by these markers among these accessions was $67.86 \%$. Genetic diversity revealed by Jaccard's co-efficient was between $0.48-0.86$. Study shows the existence of high genetic diversity among these accessions.
\end{abstract}

\section{Introduction}

Cordia dochotoma Forst is a medium sized tree with a short, usually crooked trunk (90-100 cm girth) and bearing globose fruits. It grows in India, Srilanka and other warmer countries (Kuppast, 2006; Rastogi, 1993; Kapoor, 1994) It has alternate corinaceous, obtuse, ovate, elliptic, or orbicular leaves, flowers white, polygamous, in axillary and terminal, cymose panicles. The inflorescence carries numerous white flowers. Fruits are rounded to ovoid drupe, about 1.0 to $1.9 \mathrm{~cm}$ in length, $0.9-1.74 \mathrm{~cm}$ in width, arranged in clusters. (Cappers, 2006; Kislev, 2008) Their whiteyellow color turns blackish when dry. The fruit pulp is very mucilaginous, is edible and has a sweetish flavor. It can be consumed fresh, dry and pickled. The fruits are cooling, astringent emollient, expectorant, 
anthelmintic, purgative and diuretic (Yoganarsimhan, 2000). Fruit pulp has antimicrobial activity (Mulani et al., 2013)and pharmacological properties such as analgesic, antiinflammatory and the hpatoprotective activity. (Wassel et al., 1987, Rapisarda et al., 1992) A literature review shows that though Cordia dichotoma has been reported to have a number of beneficial effects on diverse experimental parameters. Its possible role in experimental cerebral ischemia has not yet been explored. (Samadia, 2007)

\section{Materials and Methods}

\section{Plant Material}

Leaves, fruits, and seeds were collected from different selected germplasms from farmers fields of 10 different villages of four talukas in Nanded district of Maharashtra. (Table 1) in June-Jully. The germplams were named as NCd1 to NCd10.

\section{Morphological Characters and Data Analysis}

Ten accessions of 10 years old tree were selected for morphological characterization. Eleven morphological characters (Table 2) including leaf, immature and mature fruit, pulp and stone (seed) were recorded (Vashishtha et al., 1985; Nagar and Fageria, 2006; Samadia, 2007).

\section{Genomic DNA Extraction}

$0.1 \mathrm{~g}$ of leaf tissue was weighed and incubated with extraction buffer (2\% Cetyl trimethyl ammonium bromide (CTAB), $0.5 \% \beta$-mercaptoethanol etc.,) to lyse the cell wall and membrane. The lysate was then treated with Phenol:Chloroform:Iso-amyl alcohol mixture to eliminate complex organic intracellular contents. Finally, DNA was precipitated using chilled 70\% Alcohol and eluted in $40 \mu 1$ of TE-RNase, which was visualized using Agarose gel Electrophoresis, stained with Ethidium bromide. (Doyle, 1990)

\section{Random Amplified Polymorphic DNA using Polymerase Chain Reaction (RAPD)}

The genomic DNA obtained was amplified using RAPD primers of the BE series: OPBE-01, 02, 03, 08, 09. The PCR cocktail containing $10 \mathrm{pM}$ of primers, $25 \mu \mathrm{M}$ of each dNTP, $1.5 \mathrm{mM} \mathrm{MgCl} 2$ and $1 \mathrm{IU}$ of Taq polymerase, along with $\sim 100 \mathrm{ng}$ of template, was found to be optimal for the required reaction. The amplification was carried out using 30 cycles of a thermal profile containing $94^{\circ} \mathrm{C}$ for $30 \mathrm{~s}, 32^{\circ} \mathrm{C}$ for 1 minute to allow the annealing of the primers, and $72^{\circ} \mathrm{C}$ for $5 \mathrm{~min}$, followed by final extension for $2 \mathrm{~min} 50 \mathrm{~s}$. The resultant amplicons were resolved using $1 \%$ agarose gel electrophoresis and visualized with ethidium bromide staining. (Lamboy, 1994; Lamboy, 1994; Garcia-Vallvé, 1999).

\section{Data Analysis}

Based on the primary data (presence or absence of bands), pair wise genetic distance between samples were calculated using UPGMA. All the amplified bands were counted manually along with their size. The presence of bands were scored as ' 1 ' and absence as ' 0 '. A pair-wise matrix of genetic distances between genotypes was determined using the Jaccard's similarity coefficient and a phylogenetic tree was constructed using NTSYSpc-2.02e version 2.0.(Nagy, et al., 2012)

\section{Results and Discussion}

\section{Morphological Variation}

Wide variation was observed among the ten accessions of Cordia dichotoma germplasm 
on various morphological parameters of leaf, fruits and stone(seed) (Table 2)The leaf shape of most of the accessions is round or ovate as they have length and width almost equal except for $\mathrm{NCd} 3$ collected from Barad and and $\mathrm{NCd} 7$ collected from Pawdewadi which has oval leaves. Number of fruit set per cyme was greatly reduced and average percent fruit set to number of flowers per cyme was only 12.24 In most of the germplasms fruits are oval or round shape. While in germplasm NCd5 which was collected from S.R.T.M. University campus Vishnupuri the fruits are oval elongated shape (Table.2).

Fruit weight at pickle stage and ripe stage was found maximum in the accession $\mathrm{NCd} 7$ collected from Pawdewadi and the fruit weight was $3.65 \mathrm{~g}$ and $4.95 \mathrm{~g}$ respectively followed by $\mathrm{NCd} 8$ collected from Limbgaon $(4.54 \mathrm{~g})$. Average pulp:stone ratio per 10 fruits was 4.20 and the maximum being 6.34 (NCd9) collected from patnoor followed by 6.13 (NCd8) collected from Limbgaon (Table 2).

\section{Molecular Diversity}

Among 45 bands amplified by 5 primers, 37 were polymorphic, and average number of bands per primer was 9.0 and average number of polymorphic bands per primer was 7.4,. The band size observed was 1802000bp.The average polymorphism was 67.86.(Table.3) Maximum number of bands given by OPBE-08(10), followed by OPBE01(9).Percent polymorphism varied between 57.77 and $81.25 \%$.

Maximum polymorphism (81.25\%) (Table.2.) by OPBE-09. Jaccard's similarity co-efficient among these accessions was 0.48-0.86. (Table.3)Highest similarity was found between accessions of $\mathrm{NCd} 2$ collected from Mudhkhed with NCd6, collected from
Bhokar NCd8 collected from Limbgaon. Phylogenetic analysis showed that there were three groups found among the accessions (Fig. 1). group I had highest similarity co-efficient of 0.86 and the lowest was group (0.62).

Phylogenetic tree constructed based on ten accessions of Cordia dichotoma germplasm analysed by RAPD primers by UPGMA method and Jaccard's similarity coefficient using NTSYSpc-2.02e version 2.0.1.5 software. Vertical distance is arbitrary and horizontal distance indicates genetic variations among different germplasms.

The Cordia dichotoma is one of the underutilized fruit trees, escaping from orchard cultivation. To bring under systematic cultivation the superior genotype of Cordia dichotoma needs to be identified, which requires an ideal genotype having oval-round shaped fruit, green to dark green unripe mature stage and big size (9-12 g), high pulp: stone ratio with high yielding and longer harvesting period (Samadia, 2005).

This study has identified a superior genotype, NCd7, which fulfils most of the criteria and in addition it has higher fruit set per cyme. The yield potential of this accession has to be tested in multiple locations to allow this accession to be released as a variety for commercial cultivation. This genotype can be utilized to harness the potential usage in liquor and processed food industries.

Antioxidant activity of methanolic extract of fruit of C.dichotoma populations collected from different geographical regions in Nanded district were done by Nandedkar and Mulani (2013)and observed that there is variation in phytochemical constituents and antioxidant activity among the different populations. 
Table.1 Details of different genotypes of Cordia dichotoma populations and collection sites in Nanded district of Maharashtra

\begin{tabular}{|c|c|l|l|c|c|}
\hline Sr. No. & Accession No. & Village/district & Collection site & Latitude 'N' & Longitude 'S' \\
\hline 1 & NCd1 & Ardhapur/Nanded & Farmers' field & 19.28 & 77.37 \\
\hline 2 & NCd2 & Mudkhed/Nanded & Farmers' field & 19.14 & 77.49 \\
\hline 3 & NCd3 & Barad/Nanded & Farmers' field & 19.18 & 77.42 \\
\hline 4 & NCd4 & Tamsa/Nanded & Forest area & 17.40 & 78.48 \\
\hline 5 & NCd5 & Vishnupuri/Nanded & University campus & 19.10 & 77.28 \\
\hline 6 & NCd6 & Bhokar/Nanded & Farmers' field & 19.22 & 77.67 \\
\hline 7 & NCd7 & Pawadiwadi/Nanded & Farmers' field & 19.15 & 77.33 \\
\hline 8 & NCd8 & Limbgaon/Nanded & Farmers' field & 19.17 & 77.20 \\
\hline 9 & NCd9 & Patnoor/Nanded & Farmers' field & 17.22 & 78.32 \\
\hline 10 & NCd10 & Vishnupuri /Nanded & University campus & 19.10 & 77.28 \\
\hline
\end{tabular}

NCd--- N= Nanded, $\mathbf{C d}=$ Cordia dichotoma

Fig.1 Phylogenetic Tree of selected germplasm of Cordia dichotoma populations from Nanded district in Maharashtra

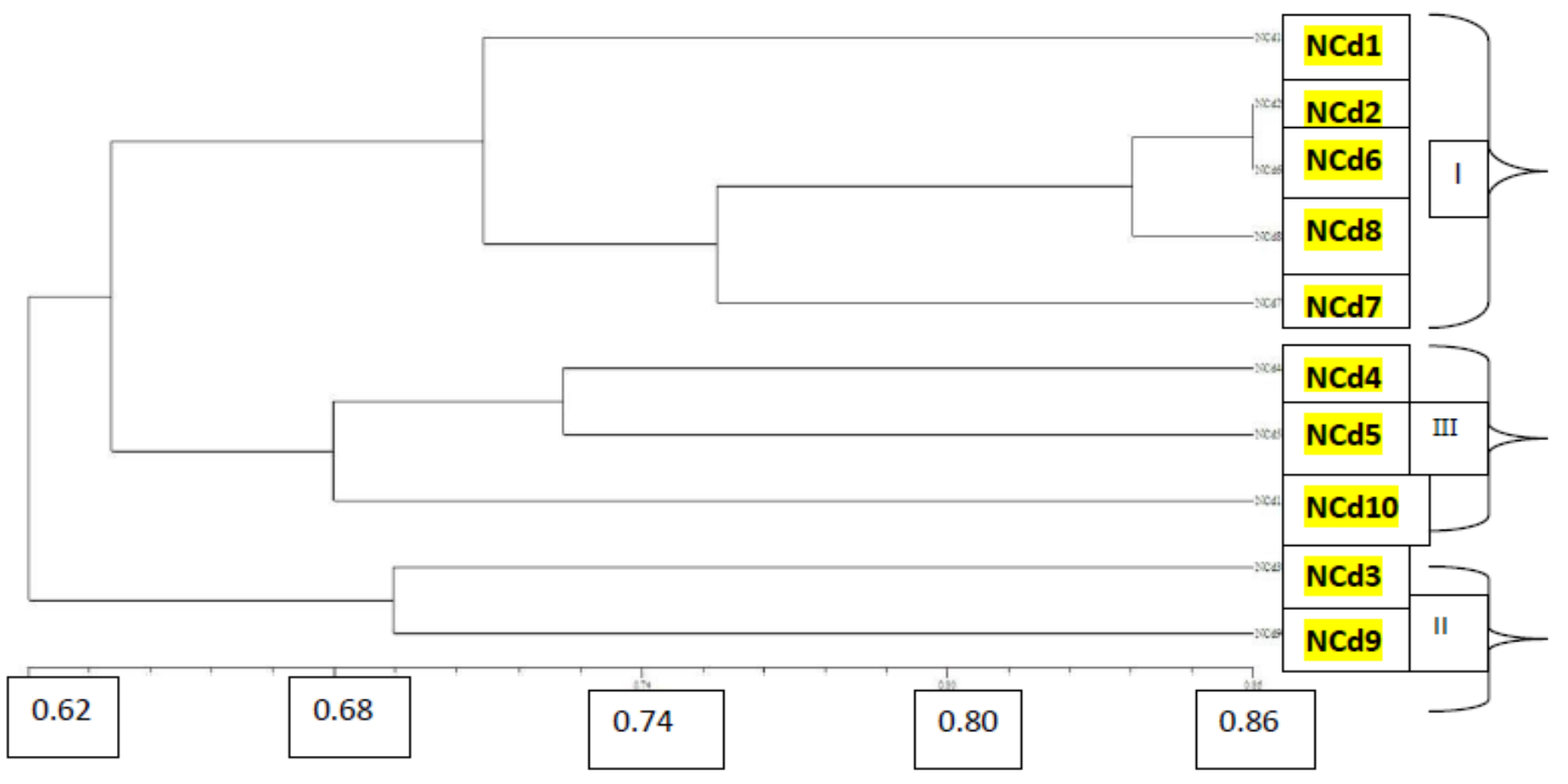


Table.2 Morphological variation of selected germplasm of Cordia dichotoma from Nanded district of Maharashtra

\begin{tabular}{|c|c|c|c|c|c|c|c|c|c|c|c|}
\hline AC. No. & $\begin{array}{l}\text { Leaf length } \\
\quad(\mathrm{cm})\end{array}$ & $\begin{array}{l}\text { leaf width } \\
\quad(\mathrm{cm})\end{array}$ & $\begin{array}{c}\text { Fruit } \\
\text { length } \\
\text { (cm) }\end{array}$ & $\begin{array}{c}\text { Fruit } \\
\text { width } \\
(\mathbf{c m})\end{array}$ & $\begin{array}{c}\text { Mature } \\
\text { fruit } \\
\text { weight } \\
\text { (gm) }\end{array}$ & $\begin{array}{c}\text { Ripen } \\
\text { fruit } \\
\text { weight } \\
\text { (gm) }\end{array}$ & $\begin{array}{l}\text { No. of } \\
\text { Fruits } \\
\text { /cyme }\end{array}$ & $\begin{array}{c}\text { Seed } \\
\text { length } \\
(\mathrm{cm})\end{array}$ & $\begin{array}{c}\text { Seed } \\
\text { width } \\
(\mathrm{cm})\end{array}$ & $\begin{array}{c}\text { Seed } \\
\text { weight } \\
\text { (gm) }\end{array}$ & $\begin{array}{l}\text { Pulp- } \\
\text { Stone } \\
\text { ratio } \\
(/ \mathbf{1 0 g m})\end{array}$ \\
\hline NCd1 & $6.79 \pm 0.10$ & $5.40 \pm 0.10$ & $1.07 \pm 0.02$ & $1.02 \pm 0.01$ & $1.35 \pm 0.02$ & $2.02 \pm 0.02$ & $7.40 \pm 1.10$ & $0.84 \pm 0.02$ & $0.81 \pm 0.01$ & $0.54 \pm 0.02$ & $3.26 \pm 0.02$ \\
\hline $\mathrm{NCd} 2$ & $7.42 \pm 0.09$ & $5.92 \pm 0.18$ & $1.13 \pm 0.01$ & $0.93 \pm 0.02$ & $1.98 \pm 0.02$ & $2.44 \pm 0.03$ & $7.05 \pm 1.19$ & $0.69 \pm 0.04$ & $0.66 \pm 0.04$ & $0.25 \pm 0.00$ & $2.91 \pm 0.20$ \\
\hline NCd3 & $10.42 \pm 0.14$ & $7.90 \pm 0.18$ & $1.24 \pm 0.01$ & $0.96 \pm 0.02$ & $1.19 \pm 0.02$ & $3.02 \pm 0.03$ & $6.10 \pm 0.91$ & $1.00 \pm 0.02$ & $0.71 \pm 0.11$ & $0.97 \pm 0.01$ & $2.54 \pm 0.02$ \\
\hline NCd4 & $8.11 \pm 0.21$ & $6.45 \pm 0.20$ & $1.06 \pm 0.02$ & $0.81 \pm 0.02$ & $0.98 \pm 0.02$ & $2.43 \pm 0.05$ & $8.00 \pm 1.30$ & $0.82 \pm 0.01$ & $0.80 \pm 0.02$ & $1.04 \pm 0.01$ & $2.12 \pm 0.01$ \\
\hline NCd5 & $6.30 \pm 0.18$ & $5.39 \pm 0.15$ & $1.83 \pm 0.01$ & $1.05 \pm 0.02$ & $2.34 \pm 0.02$ & $3.67 \pm 0.02$ & $6.20 \pm 0.95$ & $1.29 \pm 0.01$ & $0.87 \pm 0.06$ & $1.21 \pm 0.01$ & $4.12 \pm 0.01$ \\
\hline NCd6 & $8.56 \pm 0.12$ & $7.29 \pm 0.15$ & $1.22 \pm 0.02$ & $0.63 \pm 0.01$ & $1.57 \pm 0.02$ & $3.98 \pm 0.02$ & $8.05 \pm 0.89$ & $0.97 \pm 0.01$ & $0.39 \pm 0.09$ & $0.72 \pm 0.01$ & $2.85 \pm 0.02$ \\
\hline $\mathrm{NCd} 7$ & $10.37 \pm 0.16$ & $9.39 \pm 0.17$ & $1.94 \pm 0.02$ & $1.56 \pm 0.02$ & $3.66 \pm 0.03$ & $4.95 \pm 0.03$ & $10.30 \pm 1.22$ & $1.55 \pm 0.02$ & $1.53 \pm 0.01$ & $0.52 \pm 0.01$ & $6.71 \pm 0.02$ \\
\hline NCd8 & $6.49 \pm 0.18$ & $5.58 \pm 0.19$ & $1.34 \pm 0.01$ & $1.24 \pm 0.02$ & $3.12 \pm 0.01$ & $4.65 \pm 0.02$ & $8.00 \pm 1.17$ & $1.00 \pm 0.01$ & $0.99 \pm 0.02$ & $0.43 \pm 0.01$ & $6.14 \pm 0.02$ \\
\hline NCd9 & $4.51 \pm 0.17$ & $3.34 \pm 0.18$ & $1.04 \pm 0.02$ & $0.91 \pm 0.02$ & $1.47 \pm 0.02$ & $3.44 \pm 0.02$ & $10.10 \pm 1.29$ & $0.82 \pm 0.01$ & $0.80 \pm 0.02$ & $0.35 \pm 0.01$ & $6.35 \pm 0.01$ \\
\hline NCd10 & $3.10 \pm 0.20$ & $2.94 \pm 0.16$ & $1.83 \pm 0.02$ & $1.75 \pm 0.03$ & $2.78 \pm 0.02$ & $4.01 \pm 0.02$ & $6.10 \pm 0.91$ & $1.23 \pm 0.01$ & $1.20 \pm 0.02$ & $0.92 \pm 0.01$ & $5.10 \pm 0.01$ \\
\hline $\begin{array}{c}\text { Mean } \pm \\
\text { SD }\end{array}$ & $7.20 \pm 2.22$ & $5.96 \pm 1.87$ & $1.37 \pm 0.34$ & $1.09 \pm 0.33$ & $2.04 \pm 0.86$ & $3.46 \pm 0.93$ & $7.73 \pm 1.80$ & $1.02 \pm 0.25$ & $0.87 \pm 0.30$ & $0.70 \pm 0.31$ & $4.21 \pm 1.65$ \\
\hline
\end{tabular}

Ac.No-Accession No.

LL- Leaf length (cm)

LW-leaf width $(\mathrm{cm})$

FL-Fruit length (cm)

FW-Fruit width $(\mathrm{cm})$

M.Fr.w-Mature fruit weight (gm)
NOF-Number of Fruits per cyme

SL-Seed length $(\mathrm{cm})$

SW-Seed width $(\mathrm{cm})$

SWt-Seed weight (gm)

Pulp-Stone ratio.(/10gm)

R.Fr.W.Ripen fruit weight(gm)

\begin{tabular}{|l|l|}
\hline Cluster-I & NCd1,NCd2,NCd6,NCd7,NCd8 \\
\hline Cluster-III & NCd4,NCd5,Ncd10 \\
\hline Cluster-II & NCd3,NCd9 \\
\hline
\end{tabular}


Table.3 Details of primers selected for RAPD

\begin{tabular}{|l|l|c|c|c|}
\hline Sr.No. & Primers & Sequences & Total no. bands & Percent polymorphism \\
\hline 1 & OPBE-01 & CACTCCTGGT & 09 & 66.66 \\
\hline 2 & OPBE-02 & ACGCCTGTAG & 09 & 57.77 \\
\hline 3 & OPBE-03 & TGGACTCGGT & 09 & 66.66 \\
\hline 4 & OPBE-08 & GGGAAGCGTC & 10 & 67.00 \\
\hline 5 & OPBE09 & CCCGCTTTCC & 08 & $\mathbf{8 1 . 2 5}$ \\
\hline
\end{tabular}

Table.4 Jaccard's similarity co-efficient of selected germplasm of Cordia dichotoma populations from Nanded district in Maharashtra

\begin{tabular}{|l|l|l|l|l|l|l|l|l|l|l|}
\hline & NCd1 & NCd2 & NCd3 & NCd4 & NCd5 & NCd6 & NCd7 & NCd8 & NCd9 & NCd10 \\
\hline NCd1 & $\mathbf{0 . 0 0 0}$ & & & & & & & & & \\
\hline NCd2 & $\mathbf{0 . 6 8 7}$ & $\mathbf{0 . 0 0 0}$ & & & & & & & & \\
\hline NCd3 & $\mathbf{0 . 5 8 8}$ & $\mathbf{0 . 7 0 5}$ & $\mathbf{0 . 0 0}$ & & & & & & & \\
\hline NCd4 & $\mathbf{0 . 6 3 6}$ & $\mathbf{0 . 7 0 5}$ & $\mathbf{0 . 6 5}$ & $\mathbf{0 . 0 0}$ & & & & & & \\
\hline NCd5 & $\mathbf{0 . 7 0 9}$ & $\mathbf{0 . 6 7 6}$ & $\mathbf{0 . 6 2}$ & $\mathbf{0 . 7 2}$ & $\mathbf{0 . 0 0 0}$ & & & & & \\
\hline NCd6 & $\mathbf{0 . 6 6 6}$ & $\mathbf{0 . 8 6 2}$ & $\mathbf{0 . 6 8}$ & $\mathbf{0 . 6 8}$ & $\mathbf{0 . 6 5 6}$ & $\mathbf{0 . 0 0}$ & & & & \\
\hline NCd7 & $\mathbf{0 . 7 1 8}$ & $\mathbf{0 . 7 3 5}$ & $\mathbf{0 . 6 3}$ & $\mathbf{0 . 6 8}$ & $\mathbf{0 . 6 5 7}$ & $\mathbf{0 . 7 1}$ & $\mathbf{0 . 0 0}$ & & & \\
\hline NCd8 & $\mathbf{0 . 7 7 4}$ & $\mathbf{0 . 8 4 3}$ & $\mathbf{0 . 6 8}$ & $\mathbf{0 . 6 8}$ & $\mathbf{0 . 6 1 1}$ & $\mathbf{0 . 8 3 3}$ & $\mathbf{0 . 8 1}$ & $\mathbf{0 . 0 0}$ & & \\
\hline NCd9 & $\mathbf{0 . 5 0 0}$ & $\mathbf{0 . 6 4 8}$ & $\mathbf{0 . 6 9}$ & $\mathbf{0 . 6 0}$ & $\mathbf{0 . 6 2 1}$ & $\mathbf{0 . 5 4 0}$ & $\mathbf{0 . 6 7}$ & $\mathbf{0 . 5 8}$ & $\mathbf{0 . 0 0}$ & \\
\hline NCd10 & $\mathbf{0 . 6 2 5}$ & $\mathbf{0 . 6 0 0}$ & $\mathbf{0 . 5 1}$ & $\mathbf{0 . 6 4}$ & $\mathbf{0 . 7 1 8}$ & $\mathbf{0 . 4 8 5}$ & $\mathbf{0 . 6 2}$ & $\mathbf{0 . 5 4}$ & $\mathbf{0 . 6 8}$ & $\mathbf{0 . 0 0 0}$ \\
\hline
\end{tabular}

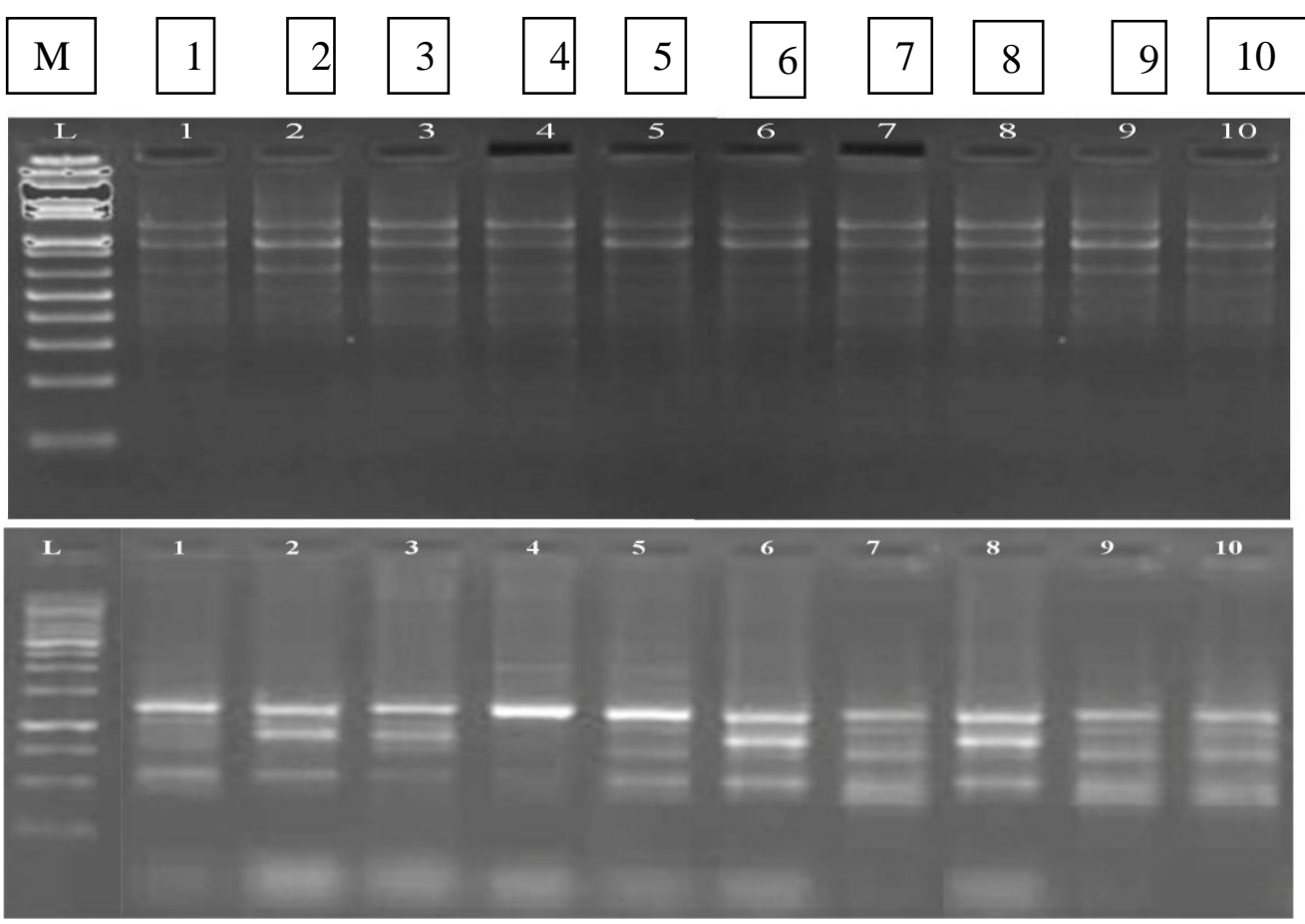

OPBE-01

OPBE-02 


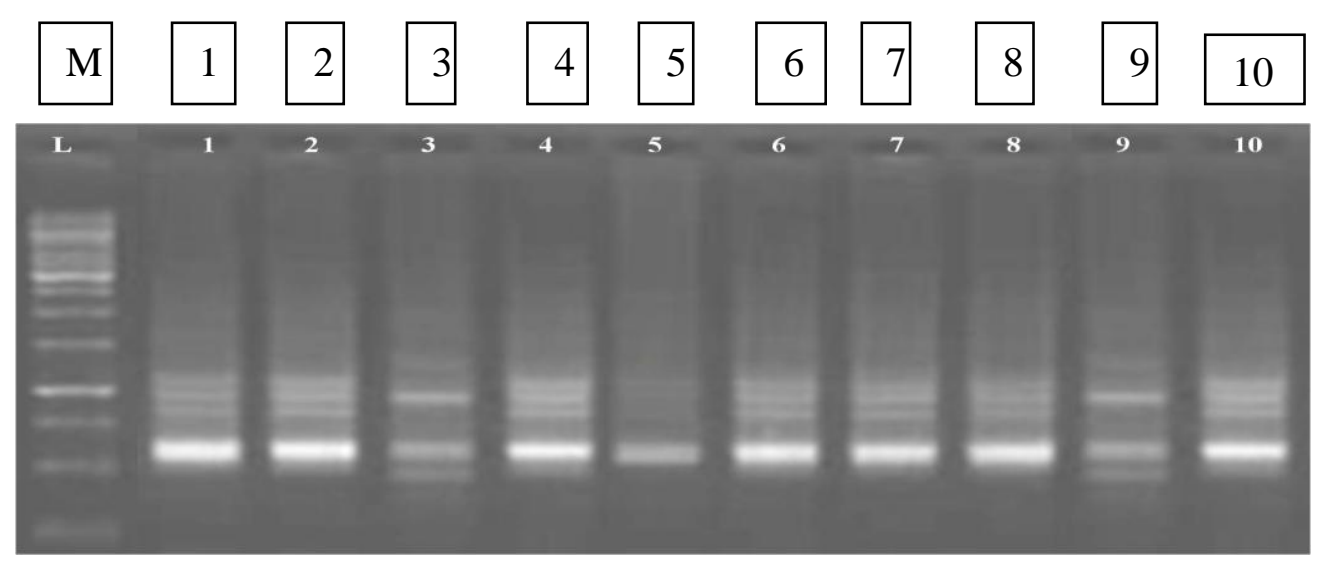

OPBE-03

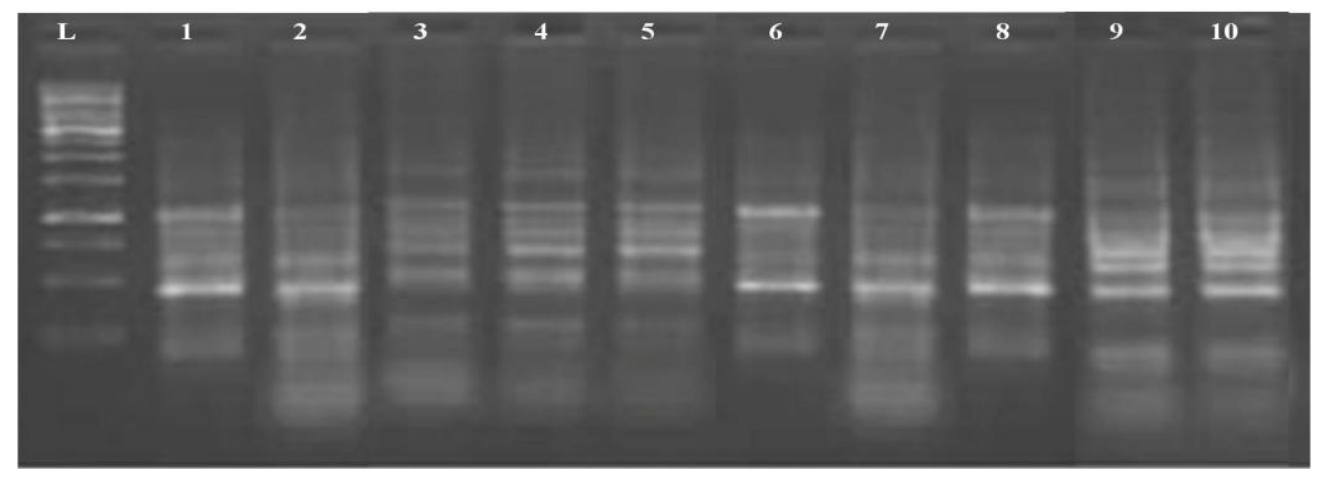

\section{OPBE-08}

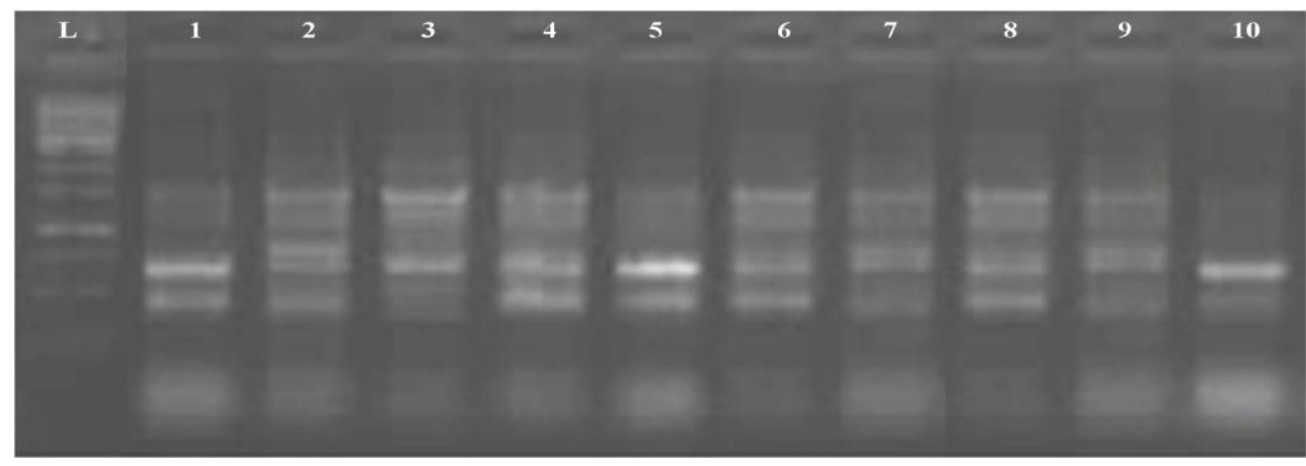

OPBE-09

Fig.2 Gel image of Fig.2. Gel image of (Polymorphism) the selected Ten accessions of Cordia dichotoma germplasm revealed by RAPD primers. Lane L-1 kb DNA ladder; lane 1NCd1(Ardhapur) : lane 2-NCd2(Mudhkhed); lane 3-NCd3(Barad); lane 4-NCd4(Tamsa); lane 5-NCd5(Vishnupuri); lane6-NCd6(Bhokar); lane 7-NCd7(Pawdewadi); lane 8NCd8(Limbgaon); lane 9-NCd9(Patnoor): lane 10-NCd10(Vishnupuri).

Genetic diversity in C.dichotoma from arid region of Rajesthan was investigated by Sivlingam (2012) and reported that there is much variation in fruits morphological character as well as molecular observations. Importance of Randomly Amplified
Polymorphic DNA (RAPD) marker in plants have been increased which gives important cluses about ecological and morphological variations in the plant species. (Kumar, 2011) 
Even molecular analysis in other plant species were done by many workers in different plants like in Rauvolfia tetraphylla by Mahesh et al., (2008); in Jatropha curcus by Subramanyam (2010); in sugarcane by Kanwar et al., (2009); in Azadirachta indica by Dhillon et al., (2007); in Bunium persicum populations by Hashemi et al., (2010); in Artemisia judaica by AlRawashdeh (2011) and RAPD markers are used in ahthentication of medicinal plants like Cuscuta reflexa(Khan et al., 2010) and this technique is also used in separation of biovers of Ralstonia solaneaceae genotypes in Capsicum annum and Solanum tuberosum from Nanded district of Maharashtra.

In conclusion, the genotypes of Cordia dichotoma has morphological variation. The molecular variation indicated by phylogenetic tree. The ten genotypes has divided in three clusters .Cluster-I includes genotypes $\mathrm{NCd} 1, \mathrm{NCd} 2, \mathrm{NCd} 6, \mathrm{NCd} 7, \mathrm{NCd} 8$, Cluster-II includes NCd3 and NCd9,ClusterIII has NCd4,NCd5,NCd10.

\section{Acknowledgments}

Authors wish to thank Director DST -FIST and UGC-SAP Sponsored, School of Life Sciences, S.R.T.M. University, Nanded for providing necessary laboratory facilities to conduct experimental work.

\section{References}

Al-Rawashdeh, M. 2011. Genetic variability in medicinal plant Artemisia judaica using Random amplified polymorphic DNA (RAPD) markers, Int. J. Agri. Biol., 13: 279-282.

Cappers, R. 2006. Roman Foodprints at Berenike. Monograph 55 (Costen Institute of Archaeology, Los Angeles).

Dhillon, R., Mohapatra, T., Sing, S., Boora, K., Sing, K. 2007. Assessment of genetic diversity in Azadirchta indica based on DNA fingerprinting. Indian J. Biotechnol., 6: 519-524.

Doyle, J., Doyle J. 1990. Isolation of plant DNA from fresh tissue. Focus, 12: 13-15.

Garcia-Vallve, S., Palau, J., Romeu, A. 1999. Horizontal gene transfer in glycosyl hydrolases inferred from codon usage in Escherichia coli and Bacillus subtilis. Mol. Biol. Evol., 16: 1125-1134.

Hoda, H., Abbas, S., Abdolreza, B. 2010. The use of RAPD marker for assessing the genetic diversity of Bunium persicum (BOISS) fettsch polulations. Int. J. Sci. Nature, 1: 202-208.

Kapoor, L. 1994. Hand book of Ayurvedic Medicinal Plants 1 st ed (CRC Press Washigton DC), 180.

Kislev, M. 2008. Archaeobotanical evidence of birdliming at Ashkelon (In: Stager LE, Schloen JD)

Kumar, P., Devarumath, Nerkar, Y. 2009. Use of RAPD markers of assessment of genetic diversity cultivars., Ind. $J$. Biotechnol., 8: 67-71.

Kuppast, J., Vasudev, N. 2006 Wound healing activity of Cordia dichotoma Frost .f fruits. Nat. Prod. Rad., 5: 99.

Lamboy, W. 1994 Computing Genetic Similarity Coefficients from RAPD Data: The Effects of PCR Artifacts . Genome Res., 4: 38-43.

Mahesh, R., Nirmalkumar, N., Merisujin, R. 2008. Molecular analysis in Rauvalfia tetraphylla L.using RADP markers. Ethanobotanical leaflets, 12: 1129-36.

Master, D. 1985-2006. (eds) Ashkelon 1. Introduction and overview (Eisenbrauns, Winona Lake), 131137.

Mulani, R., Nandedkar, P., Solankar, B. 2013. Phytochemical estimations and 
antimicrobial activity of methanolic and acetone extracts of Cordia dichotoma. Asian J. Phytomedicine And Clinical Res., 1: 211-217.

Mulani, R., Nandedkar, P. 2015. Antioxidant Activity of methanolic extract of Cordia dichotoma collected from different geographical region. Int. J. Sci. Res., 4: 12941299.

Nagar, B., Fageria, M. 2006. Genetic divergence in Lasura (Cordia myxa Roxb.). Indian J. Genet, 66: 67-68.

Nagy, S., Poczai, P., .Cernák, I., Gorji, A.M., Hegedü, G., Taller, 2012. PICcalc: an online program to calculate polymorphic information content for molecular genetic studies. J. Biochemical genetics, 50: 670-672.

Rapisarda, A., Ficarra, R., Tommasin, S., Caldbro, M., Hungsa, S. 1992. Cordia francisci, C. martinicensis, C. myxa, C. serratifolia and $C$ .ulmfolia leaves as new source of routine; Analgesic and antiinflammatory activity, Planta Medica, 42: 643.

Rastogi, R. 1993. Compendium of Indian Medicinal plant, (C D R I Publication New Delhi), 221.

Salim, K., Khanda, J., Malik, Z. 2009. Development of RAPD markers for authentication of medicinal plant Cuscuta reflexa, Eroasian $J$. biosciences, 4: 1-7.

Samadia, D. 2005. Genetic variability studies in Lasora (Cordia myxa Roxb.). Indian J. Plant Genetic Resources, 18: 236-240.

Samadia, D. 2007. Variability and Scope of Improvement in Lasora (Cordia myxa), Indian J. Agrofor., 9: 111115.

Sivlingam, P., Dhurendra, S. 2012. Morphological and molecular diversity of an underutilized fruit crop-Cordia myxa L. germplaslm from arid region of Rajesthan,India, Genet. Res. crop evol., 59: 305-316.

Subraramnanyam, K., Dowlathabad, M., Devanna, N., Arvinda, A., Pandurangdau, V. 2010. Evaluation of genetic diversity among Jatropha curcus (L.) by RAPD analysis, Ind. J. Biotechnol., 9: 283-288.

Vashishtha, B., Ram, R. 1985. Singh, Studies on flowering and fruiting of lasoda (Cordia myxa). Haryana, $J$. Hortic. Sci., 14: 156-159.

Wassel, G., El-Menshaw, B., Saud, A., Meharuna, G., El-Merzabani, M. 1987. Screening of selected plant for Pyrrolizidine alkaloids and antitumor activity, Pharmazine, 42: 709.

Yoganarsimhan, S. 2000. Medicinal Plants of India, Vol. 1, (Interline publishing Pvt. Ltd., Bangalore, Karnataka), 38.

\section{How to cite this article:}

Pushpa H. Nandedkar and Ramjan M. Mulani. 2016. Morphological and Molecular Diversity of Cordia dichotoma Frost F. Populations from Nanded District in Maharashtra, India. Int.J.Curr.Microbiol.App.Sci. 5(6): 135-143. doi: http://dx.doi.org/10.20546/ijcmas.2016.506.017 